\title{
DEDUCTIBILITY OF ILLEGAL EXPENSES UNDER SECTION 162 OF THE INTERNAL REVENUE CODE: A JUSTIFICATION FOR VAGUENESS *
}

The deductibility of illegal expenses for "any trade or business" under section 162 of the Internal Revenue Code ${ }^{1}$ has been a much debated, but never resolved, problem for federal courts. The section allows a taxpayer to deduct from gross income all "ordinary and necessary" business expenses without differentiation as to kind. Although Congress has consistently refused to qualify the statute, ${ }^{2}$ the courts, by a process of "judicial gloss," have disallowed deductions of many expenses, whether illegal or not, whose purpose violates some declared public policy. ${ }^{3}$ Thus, deductibility has been denied for such ex-

*Commissioner v. Doyle, 231 F.2d 635 (7th Cir. 1956).

1. INT. REv. CoDE of 1954, § 162, formerly Int. Rev. Code of 1939, $\$ 23$ (a) (1), 53

Stat. 12. Relevantly, the section reads:

"IN General-There shall be allowed as a deduction all ordinary and necessary expenses paid or incurred during the taxable year in carrying on any trade or business including-(1) a reasonable allowance for salaries. ... (3) rentals or other payments. ..."

2. Congress has rejected provisions which would deny deductions for illegal expenses. 50 Cong. REc. 3850 (1913). The object of the Revenue Act of 1913, the language of which in regard to this section has been carried forward, was not "to reform men's moral characters." See $50 \mathrm{id}$. at 3849:

"[T]he tax is framed for the purpose of making a man pay upon his net income, his actual profit during the year. The law does not care where he got it from, so far as the tax is concerned, although the law may very properly care in another way."

In 1951 Senator Kefauver sought unsuccessfully to amend $\S 162$ by prohibiting deductions "for any expense paid or incurred in or as a result of illegal wagering." $97 i d$. at 12230-31, 12244 (1951). Prior to the recodification of the Code in 1954 the American Law Institute unsuccessfully recommended that Congress change the statute to disallow deductibility of illegal expenses. ALI Fed. Income TAx Stat. \$ X165(i) (1) (Feb. 1954 Draft).

See, generally, Paul, The Use of Public Policy by the Commissioner in Disallowing Deductions, 1954 So. CalrF. Tax INST. 715 (hereinafter cited as Paul).

3. J. Rossman Corp. v. Commissioner, 175 F.2d 711 (2d Cir. 1949). See Cormmissioner v. Heininger, 320 U.S. 467, 473 (1943) (expenses of contesting denial of use of mails).

Some courts have denied expense deductions on the grounds of public policy without discussing their "ordinary and necessary" nature. See, e.g., Charles A. Clark, 19 T.C. 48, 53 (1952) (bribe). Other courts at times have used the public policy standard to interpret an expense as not "ordinary and necessary." See, e.g., Israel Silberman, 44 B.T.A. 600, 603 (1941) (gambling). 
penses as bribes, ${ }^{4}$ protection payments, ${ }^{5}$ fines or penalties, ${ }^{6}$ lobbying ${ }^{7}$ and the unsuccessful defense of criminal suits. ${ }^{8}$

Through the years, the vague standard of public policy permitted courts to approach each decision on the deductibility of particular expenses flexibly. Increasingly, however, a desire for greater specificity has produced decisions suggesting violation of statute, traditionally a major ground for testing conflict with public policy, as an independent basis for nondeductibility. Courts have periodically declared that illegal expenses could never be "necessary."10 Moreover, this basis for disallowing deductibility was later advanced, through neither approved nor disapproved, by the Supreme Court. ${ }^{11}$ Attempting to define the

4. Rugel v. Commissioner, 127 F.2d 393, 395 (8th Cir. 1942) ; Frank A. Maddas, 40 B.T.A. 572, 581, aff'd, 114 F.2d 548 (3d Cir. 1940).

5. Charles A. Clark, 19 T.C. 48 (1952) ; G. A. Comeaux, 10 T.C. 201, 207 (1948), aff'd sub nom. Cohen v. Commissioner, 176 F.2d 394 (10th Cir. 1949); Charles E. Rank, 12 CCH Tax Ct. Mem. 1161, 1164 (1953); Fred D. Clemons, 7 CCH Tax Ct. Mem. 81, 84 (1948).

6. Usually cited by later cases denying deductibility, Great Northern Ry. v. Commissioner, 40 F.2d 372, 373 (8th Cir.), cert. denied, 282 U.S. 855 (1930), is the leading decision disallowing deductions for penalty payments. See Chicago R.I. \& P. Ry. v. Commissioner, 47 F.2d 990, 991 (7th Cir.), cert. denied, 284 U.S. 618 (1931) ; Burroughs Bldg. Material Co. v. Commissioner, 47 F.2d 178 (2d Cir. 1931) ; Tank Truck Rentals Inc., 26 T.C. No. 52 (May 31, 1956); Garibaldi \& Cuneo, 9 T.C. 446 (1947); Scioto Provision Company, 9 T.C. 439 (1947); The Kansas City So. Ry., 22 B.T.A. 949, 963 (1931). In recent years courts have stressed more the question of whether the penalty violates public policy. See J. Rossman Corp. v. Commissioner, 175 F.2d 711 (2d Cir. 1949). Compare also the payments allowed and denied in Hoover Motor Express Co. v. United States, 135 F. Supp. 818 (M.D. Tenn. 1955).

7. Lobbying is a legal business; yet because often considered "insidious," lobbying expenses have been disallowed. See Textile Mills Securities Corp. v. Commissioner, 314 U.S. 326, 337 (1941); American Hardware \& Equip. Co. v. Commissioner, 202 F.2d 126 (4th Cir. 1953). See Note, 67 Harv. L. Rev. 1408, 1415 (1954), stating that the Commissioner has conservatively applied the regulation denying deductibility for lobbying expenses, limiting nondeductibility mostly to businesses with an "unsavory reputation." Compare, however, Revere Racing Ass'n, Inc. v. Scanlon, 232 F.2d 816 (1st Cir. 1956) (expenses incurred to obtain voter approval in referendum permitting extension of legalized pari-mutuel betting denied). Compare also Wm. T. Stover Co., 22 T.C. No. 48 (Nov. 30, 1956) where business selling surgical and medical supplies was denied deduction for expenses incurred in sending newspaperman to England to write articles against socialized medicine; the Tax Court based its decision upon the Textile case, supra.

S. Thomas v. Commissioner, 16 T.C. 1417 (1951); Simon Bloom, 7 CCH Tax Ct. Mem. 517 (1948); Atlantic Terra Cotta Co., 13 B.T.A. 1289 (1928).

9. See 6 Corbin, Contracts $\$$ 1373-74 (1950).

10. Gallatin Farmers Co. v. Commissioner, 132 F.2d 706, 708 (9th Cir. 1942); National Outdoor Advertising Bureau, Inc. v. Helvering, $\$ 9$ F.2d 878, 881 (2d Cir. 1937) ; Raymond F. Flanagan, 47 B.T.A. 782 (1942); Israel Silberman, 44 B.T.A. 600 (1941).

11. Lilly v. Commissioner, 343 U.S. 90, 95 (1952). The Court allowed an expense deduction for "kickbacks" in an optical business, reiterating the language of Commissioner v. Heininger, 320 U.S. 467,474 (1943), that the expense may be disallowed only if it would "frustrate . . . sharply defined policies. . ." Heininger allowed deductions for 
public policy standard, the Court stated in Commissioner v. Lilly that "it could be argued" disallowance may result by "virtue of the illegality" of the expense. ${ }^{12}$ Little occurred immediately following this opinion to establish illegality as a per se determinant of nondeductibility. ${ }^{13}$ But in recent decisions denying deduction of expenses violating state law, the Tax Court distinctly adopted the Supreme Court's dictum and held that illegality alone made an expense nondeductible as contrary to public policy. ${ }^{14}$

The reasoning of these Tax Court decisions as well as of previous opinions stressing the importance of illegality was implicitly rejected by the Court of Appeals for the Seventh Circuit in Commissioner v. Doyle. ${ }^{10}$ Without discussing either Lilly or other decisions indicating that all illegal expenses are nondeductible, the court ruled that salary payments to employees were deductible "as an integral part of a business" regardless of the illegality of the enterprise-in this instance gambling-under state law. ${ }^{16}$ The majority dis-

expenses of litigation contesting the Postmaster-General's denial of use of the mails for taxpayer's "misleading" advertisements.

12. 343 U.S. 90, 95 (1952).

13. Subsequent courts, while denying deductibility for illegal expenses, rested their decisions on grounds that the expense conflicted with public policy or that it was not "ordinary and necessary." See Joseph Karger, 13 CCH Tax Ct. Mem. 661 (1954) (abortionist's expenses). Cf. G. E. Fuller, 20 T.C. 308, 317 (1953) (business loss deduction denied for liquor confiscated by state authorities).

14. R. E. L. Finley, 27 T.C. No. 46 (Nov. 30, 1956) ; Albert D. MeGrath, 27 T.C. No. 13 (Oct. 29, 1956); James Ross, 15 CCH Tax Ct. Mem. 23 (Jan. 13, 1956) ; Sam Mesi, 25 T.C. 513, 522 (1955) ; Boyle, Flagg \& Seaman, Inc., 25 T.C. 43, 50 (1955). See 4 Mertens, Federal Income Taxation $\$ 25.09$ (Supp. 1956): "The phrase 'ordinary and necessary' has been construed to imply a condition that the payments themselves must not be illegal."

The illegality standard may have gained acceptance since Attorney General Herbert Brownell stated to the American Bar Association:

"It seems anomalous that a person engaged in a business which is admittedly illegal may take a deduction for 'ordinary and necessary expenses' incurred in the business. As either a legal or practical matter, I can see nothing ordinary or necessary in expenses incurred in long distance telephone calls made to place bets or make layoffs; automobile expenses for collecting numbers or delivering dope, rent for houses used for gambling, or other vice. But, even if they are 'ordinary' expenses, there is certainly nothing 'necessary' about them.

"Our policy in the Department will henceforth be to disallow all deductions for expenses incurred in illegal enterprise, and the Treasury Department has promised us its fullest co-operation."

Address to American Bar Association Annual Meeting, Aug. 27, 1953, 78 A.B.A. REp. 334, 338 (1953).

And on a state level, California has levied a tax on gross income of certain illegal activities to help suppress criminal activity. Comment, The Use of Taxation to Control Organized Crime, 39 CALIF. L. Rev. 226, 231 (1951).

15. 231 F.2d 635 (7th Cir. 1956).

16. Id. at 637. Bookmaking, the form of gambling involved in Doy!e, is illegal under ILL. Rev. Stat. c. 38, $\$ 336$ (1955). The court also allowed deduction of expenses for rent which had been challenged by the Commissioner. See 231. F.2d at 638 . 
regarded the dissenting opinion's suggestion and the Commissioner's argument that paying the salaries was itself illegal under another local statute declaring unlawful an act which "aids, abets or assists" illegal activities. ${ }^{17}$

The Tax Court had also allowed the deduction in Doyle, ${ }^{18}$ but its decision stands as an exception to cases invoking the illegality per se rationale decided both before and after the Seventh Circuit's ruling. Thus, Sam Mesi ${ }^{10}$ held salary expenses paid by a gambler not deductible. In Mesi, however, the Commissioner contended the aiding and abetting statute made the expenses illegal, ${ }^{20}$ an argument absent from the earlier Doyle Tax Court proceedings. And after the Seventh Circuit's Doyle decision, the Tax Court in Albert D. McGrath, ${ }^{21}$ again concerned with gambling salary expenses, approved its Mesi holding and specifically refused to adhere to the ruling of the court of appeals. ${ }^{22}$

Use of the deduction section of the Code as a medium for judicial expressions of community attitudes has been both deplored and approved. Regardless of the merits of the approach, however, it is certain to be continued. The question, then, involves the standard to be used in determining nondeductibility. A statutory basis for denying deductions exists only in the limited situations in which courts can declare the expense not "ordinary and necessary." In many cases, courts can use the language of the statute to deny deductions; for example, it is seldom customary or required of a business engaged in legal pursuits to incur illegal expenses. ${ }^{23}$ But the illegal expenses

17. Irl. Rev. Stat. c. 38, $\$ 582$ (1955). See Commissioner v. Doyle, 231 F.2d 635, 638 (7th Cir. 1956) (dissenting opinion); Brief for Appellant, p. 8, Commissioner v. Doyle, supra.

Use of the aiding and abetting statute to deny deductibility for rent would have been particularly difficult, since this theory required the landlord to know his premises were used for gambling. See Commissioner v. Doyle, supra at 638. The salary expense, however, did not pose an evidentiary problem since the employees obviously knew their work was illegal.

18. Charles V. Doyle, 13 CCH Tax Ct. Mem. 1171, 1174 (1954). The Tax Court followed its previous position that legal expenses of illegal businesses are deductible. G. A. Comeaux, 10 T.C. 201, 207 (1948); Anthony Cornero Stralla, 9 T.C. 801, 821 (1947) (dictum).

19. 25 T.C. 513 (1955).

20. Ibid. See letter from counsel for Commissioner to the Yale Law Journal, Oct. 12, 1956, on file in Yale Law Library, indicating the argument of illegality based on the aiding and abetting statute had not been thought of at the time of the Doyle Tax Court proceedings. But see BITTKER, FEDERAL I NCOME TAXatTon 250 n.5 (1954).

21. 27 T.C. No. 13 (Oct. 29, 1956).

22. Like Mesi, McGrath is appealable to the Seventh Circuit. In refusing to follow a decision of the court of appeals in whose jurisdiction the tax proceeding is litigated, these Tax Court decisions conflict with the recent decision of the Sixth Circuit in Stacey Mfg. Co. v. Commissioner, Civil Nos. 12735, 12740, 6th Cir., Nov. 2, 1956. Stacey declares that the jurisdiction of the Tax Court is like that of the district courts which must follow decisions of their respective courts of appeals.

23. Where it is not "ordinary" in the particular business to give bribes, for example, courts could strike down the deduction without regard to illegality. Or payments for 
of illegal businesses are more troublesome; such payments as illegal salaries and rents would be disallowed on statutory grounds only by obvious distortion of the statute, since section 162 specifically permits deductions of such expenses. ${ }^{24}$

The test of nondeductibility must accordingly be either the Tax Court's specific standard of illegality or a less precise criterion such as public policy. The choice of either standard is still open. The Supreme Court's Lilly decision does not compel acceptance of the Tax Court's test; the suggestion there that illegality by itself could be a basis for nondeductibility appeared in a wider discussion actually reaffirming the public policy standard. Accordingly, both standards should be judged by the extent to which each fulfills the function of the courts in deciding whether objectionable expenses are deductible and by the further problems each may raise in practice.

On balance, the inherent vagueness of such a term as "public policy" or to a lesser extent Doyle's standard of integrality, best affords the flexibility needed to reflect community views in a field largely controlled by the facts of each case. Leading decisions applying section 162 to deductions other than those for illegal expenses support the wisdom of such a vague standard. Discussing the meaning of "ordinary and necessary," the Supreme Court in Welch $v$. Helvering stressed that distinctions of "degree and not of kind" determined deductibility. ${ }^{25}$ While $W$ elch did not concern expenses whose purpose violated public policy, the Court's opinion apparently countenanced a flexible standard for decision in this area of tax law. J. Rossman Corp. v. Commissioner indicated the Second Circuit's approval of a similar approach where the expense deduction presented a question of conflict with public policy. ${ }^{2 b}$ Allowing the taxpayer to deduct a penalty expense incurred by inadvertent violation of OPA rules, Rossman rejected the Tax Court's "rigid criterion" making all penalty payments nondeductible. ${ }^{27}$ After reiterating the need for a vague standard, the court fell back on earlier language of the Supreme Court and asserted that only penalities for violations which "frustrate sharply defined public policies" were nondeductible. ${ }^{28}$ Use of the public policy standard would permit various types of illegal expenses to be likewise selectively distinguished.

In spite of its certainty, the illegality per se rationale is an inappropriate standard, since it forces federal courts to abide by state criminal statutes. Not all statutes express sharply defined policies, and those that do vary greatly in

political favors may be denied deductibility because they are not "ordinary" in the business or not "necessary" because others in the same business do not consider them so. See Rugel v. Commissioner, 127 F.2d 393, 395 (8th Cir. 1942).

24. See note 1 supra.

25. 290 U.S. 111, 114-15 (1933).

26. 175 F.2d 711 (2d Cir. 1949).

27. The court asserted: "there are 'penalties' and 'penalties' . . . some are deductible and some are not . . . in every case the question must be decided ad hoc." Id. at 713.

28. Ibid. The court referred to Lilly v. Commissioner, 343 U.S. 90 (1952) and Commissioner v. Heininger, 320 U.S. 467 (1943). See note 11 supra. 
degree of popular acceptance. ${ }^{29}$ An inflexible illegality standard ignores these necessary distinctions; the test would place organized criminal activity on a par with socially harmless individual violations of unpopular or anachronistic legislation. ${ }^{30}$ Furthermore, to the extent that some uniformity should be retained in this area of federal taxation, ${ }^{31}$ the illegality rule is equally unwise. Although state statutes determining illegality are most often substantially alike, wide differences may exist in interpretation and enforcement. For example, interpretations of essentially similar gambling statutes contrast sharply, with some activities considered legal in one locale but not in another ${ }^{32}$ derluctions of salary expenses for like services would vary arbitrarily.

Finally, by using the federal power to tax income to supplement the police power of the states over criminal law enforcement, the illegality standard may be an unconstitutional interpretation of section 162. Considered together, the Supreme Court's opinions in United States $v$. Constantine ${ }^{33}$ and United States $v$. Kahriger ${ }^{34}$ indicate that a federal tax which is actually "a penalty ... for violation of state law"35 infringes the Tenth Amendment. Thus, in

29. Oklahoma's prohibition of liquor sales is illustrative. OkLa. Stat. AnN. tit. $37, \S 1$ (Supp. 1956). See R. E. L. Finley, 27 T.C. No. 46 (Nov. 30, 1956), where the Tax Court denied expense deduction for liquor purchased by business for entertainment and promotion of good will on the ground the expense was illegal by Oklahoma statute. See also G. E. Fuller, 20 T.C. 30 S (1953), aff'd, 213 F.2d 102 (10th Cir. 1954) where a business loss deduction was denied for liquor intended for sale but confiscated by Oklahoma police authorities.

30. For example, while almost all states regulate Sunday activities, a few have stringent statutes which ban most commercial activity. For example, the Massachusetts law prohibiting "any manner of labor, business or work," Mass. ANN. Laws c. 136, \$\$ 5, 6 (Supp. 1956), has been interpreted to make "hauling gasoline in a tank truck" on Sunday unlawful. Commonwealth v. Crosby, 329 Mass. 54, 106 N.E.2d 538 (1952). Under a similar Connecticut statute declaring unlawful the sale of any goods and merchandise on Sunday (with a few designated exceptions), ConN. GEN. STAT. $\$ 8607$ (1949), as amended, $\$ 3302 \mathrm{~d}$ (Supp. 1955), the sale of half a pound of liverwurst was held illegal. State v. Hurliman, 143 Conn. 502, 123 A.2d 767 (1956). And while permitting the sale of butter under a dairy products category, the statute prohibits the selling of oleomargarine, a vegetable product. Thus milkmen have been fined for selling oleo on Sunday. See New Haven Register, Nov. 26, 1956, p. 1. See, generally, Note, 61 Yale L.J. 427 (1952).

31. Paul, The Effect on Federal Taxation of Local Rules of Property, in Selected Studies in Federal Taxation (Second Series) 1, 49-52 (2d ed. 1938). See Jerome v. United States, 318 U.S. 101, 104 (1943) :

"[W]e must generally assume, in the absence of a plain indication to the contrary, that Congress when it enacts a statute is not making the application of the federal act dependent on state law. That assumption is based on the fact that the application of federal legislation is nationwide. . .."

See also Burnet v. Harmel, 287 U.S. 103, 110 (1932).

32. Thus, while most states have laws against lotteries, judicial interpretation of "consideration" as an element varies considerably. In certain states, "giveaway" practices are considered illegal lotteries. And "Bank Nights" in theatres are sometimes outlawed for the same reason. See Note, 33 U. DET. L.J. 71 (1955).

33. 296 U.S. 287 (1935).

34. 345 U.S. 22 (1953).

35. 296 U.S. at 296. See also 97 Cong. Rec. 12230-31, 12244 (1951) interpreting 
Kahriger the Court upheld an excise because its operation was not determined by state illegality; in Constantine congressional reliance on local illegality to impose the tax resulted in unconstitutionality. ${ }^{36}$

While these Supreme Court decisions concerned taxes and not deductions, this distinction should not be relevant. True, as repeatedly stated, deductions are a matter of "legislative grace," Congress to tax gross income. ${ }^{38}$ As a practical matter, however, disallowing a deduction may effect the same "penalty" as a tax levied on illegal activities. Furthermore, in denying illegal expenses courts do not act under a legislative mandate; the Tax Court's standard is imposed without concern for congressional intent ${ }^{39}$ and often by ignoring the statutory standard itself. ${ }^{40}$ In $\mathrm{Mlesi}$, for example, a deduction was denied although the salary expense came within the fair meaning of "ordinary and necessary" and would have been deductible even under a strict application of "legislative grace." Admittedly, the practical effect of nondeductibility is the same whether the result of judge-made rule or congressional enactment. Nevertheless, the Sixteenth Amendment, interpreted to permit taxes on gross income, supports legislative action determining standards for deductions. ${ }^{41}$ Courts, on the other hand, must invoke the nor-

as unconstitutional Senator Kefauver's amendment to $\$ 162$ denying deduction for expenses of gambling illegal under state law.

36. Though Kahriger stated the Court would not look into the motive of Congress in passing the statute as long as the "tax produces revenue," 345 U.S. at 28 , it felt obliged to discuss and distinguish Constantine. In the latter the Court did analyze the legislative motive and found the tax, a $\$ 1,000$ excise on liquor dealers operating in violation of state law, to be a penalty despite its revenue-raising nature. In contrast, the Kahriger tax, a $\$ 50$ annual registration levy on gamblers plus a $10 \%$ excise on wagers, did not differentiate between state-determined legality or illegality. Thus, the Court declared, the tax did not infringe on the constitutional powers of the states over local law enforcement. That Congress recognized the form which the Kahriger tax had to take to secure constitutionality, see 97 ConG. Rec. 12239-40 (1951).

Any use of federal tax law to enforce state criminal law is apparently strongly objectionable to four present Justices of the Supreme Court. See United States v. Kahriger, 345 U.S. 22, 37 (1953) (Frankfurter, J., dissenting) ; Rutkin v. United States, 343 U.S. 130, 139, 141-43 (1952) (Black, J., dissenting with Reed, Frankfurter and Douglas, JJ.).

37. See New Colonial Co. v. Helvering, 292 U.S. 435, 440 (1934) ; Deputy v. du Pont, 308 U.S. 488, 493 (1940) ; Sam Mesi, 25 T.C. 513 (1955). See also Griswold, An Argument Against the Doctrine That Deductions Should Be Narrowly Construed as a Matter of Legislative Grace, 56 HARv. L. REv. 1142, 1144 (1943); Paul 721; note 41 infra.

38. See note 41 infra.

39. See note 2 supra.

40. Cf.

"Congress may be strict or lavish in its allowance of deductions or tax benefits. The formula it writes may be arbitrary and harsh in its applications. But where the benefit claimed by the taxpayer is fairly within the statutory language and the construction sought is in harmony with the statute as an organic whole, the bencfits will not be withheld from the taxpayer. ..."

Lewyt Corp. v. Commissioner, 349 U.S. 237, 240 (1955). (Emphasis added.)

41. Though Congress has not sought to tax gross income by disallowing all deductions, the Supreme Court has from time to time indicated that the legislature "has the power to 
mally less secure authority of judicial precedent and community attitude to justify a nonstatutory standard. Confronted with the objection that this standard violates the Tenth Amendment, the less authoritative judicial rule should be rejected. Even could the Tax Court's standard be invoked in the name of congressional intent, "legislative grace" should not justify a standard which conflicts with a constitutional provision." A "public policy" standard, on the other hand, avoids these pitfalls. Because its reasoning rests on broader grounds and does not necessarily become operative upon a violation of state law, that standard conforms to the Kahriger-Constantine test.

The Seventh Circuit's proposed standard of "integrality" would enable courts to implement selective denial of deductibility more effectively than the rigid "illegality" criterion; "integrality" itself, however, is susceptible to mechanical interpretation that may prevent the fullest judicial flexibility this area of the law demands. In holding that salaries paid by gamblers, or any business, were deductible under its standard, Doyle distinguished as "concomitant" but not integral, such payments as bribes, lobbying expenses and fines. ${ }^{43}$ Yet periodic bribes from the same gamblers to police authorities for protection are only verbally distinguishable from salaries to employees. ${ }^{44}$ And lobbying expenses are both common and indispensable to the very existence and growth

condition, limit or deny deductions from gross income in order to arrive at the net that it chooses to tax." See Helvering v. Independent Life Ins. Co., 292 U.S. 371, 381 (1934). See also Burnet v. Thompson Oil and Gas Co., 283 U.S. 301, 304 (1931) ; Typee Realty Co. v. Anderson, 240 U.S. 115 (1916) ; Stanton v. Baltic Mining Co., 240 U.S. 103 (1916); Brushaber v. Union Pac. R.R., 240 U.S. 1, 23, 24 (1916). The position that Congress can tax gross income has been questioned, however, since the above cases concerned only deductions for interest, depreciation and depletion. See Magill, Taxable Income 367 (rev. ed. 1945).

42. Aside from the Tenth Amendment, Congress might be barred by the due process clause of the Fifth Amendment from invoking "legislative grace" to enact legislation disallowing deduction of expenses for purposes illegal under state statute. The federal due process clause has been interpreted to include the concept of "equal protection of the laws." See Bolling v. Sharpe, 347 U.S. 497, 499 (1953). See also Dyer v. Kazuhisa Abe, 138 F. Supp. 220 (D. Hawaii 1956). Thus, it could be contended that Congress was unjustifiably discriminating against taxpayers seeking to deduct typical business expenses by disallowing deductions solely because of state determined illegality. Such legislation, however, could rest on the demands of administrative convenience and, superficially, at least, have no relation to regulatory purposes. The task of ascertaining the validity of expense deductions for illegal activities, it could be argued, is so much more difficult than for legal businesses and expenses that denial of deductions for illegal expenses would not be an unreasonable distinction. Acceptance of this rationale would overcome the due process objection. Cf. Paul 721-22. On the other hand, should Congress amend $\S 162$ to disallow deduction of illegal expenses for administrative reasons, courts might still declare such legislation unconstitutional because its real motive was regulatory. See note 36 supra.

43. 231 F.2d at 637 .

44. See Charles A. Clark, 19 T.C. 48 (1952), where the taxpayer periodically paid "rigged" fines to the city in a deal with local authorities for protection of his gambling establishment. Were it not for these payments the taxpayer obviously would have no business. 
of many legitimate industries. ${ }^{45}$ Fines are unavoidable and natural in such businesses as taxi-cab and truck operations. ${ }^{46}$ In addition the integrality test is actually inconsistent with a purpose of denying objectionable expenses, for it focuses on the "ordinary and necessary" nature of the expense rather than on the relation of the outlay to any public policy.

By contrast, the public policy standard grants courts in each of these circumstances a unique freedom and necessary discretion for determining deductibility. It enables decisions to rest on qualitative distinctions among expenses which even as vague a standard as "integrality" would apparently forbid. Public policy should accordingly be retained as the ultimate determinant of deductibility in this field. Of limited value, "integrality" and illegality should be employed only to indicate material but inconclusive evidence of conflict with this broader standard.

45. See, e.g., Revere Racing Ass'n v. Scanlon, 232 F.2d 816 (1st Cir. 1956) ("lobbying" necessary to persuade voters to approve referendum permitting extension of legalized parimutuel betting).

46. See Tank Truck Rentals Inc., 26 T.C. No. 52 (May 31, 1956) ; Hoover Motor Express Co., Inc. v. United States, 135 F. Supp. 818, 819 (M.D. Tenn. 1955) ; Bitrker, Federai Income Estate and Gift Taxation $254-55$ n.2 (1955). 